\title{
Des doses patients excessives en scanographie: de nouvelles préoccupations
}

\author{
Mots-clés : scanner / dose / sécurité patient / risque patient
}

Il est clairement établi que le scanner contribue à plus de $50 \%$ des doses aux patients (Dreuil et Etard 2017; IRSN 2020a). L'examen scanner est en soi un examen «dosant» largement utilisé du fait de sa contribution décisive au diagnostic rapide des maladies, au bilan d'extension des cancers, à l'orientation de la stratégie thérapeutique, au suivi des maladies et à l'efficacité des traitements et au traitement lui-même. Même si la mise en œuvre des niveaux de référence diagnostiques contribue efficacement à l'optimisation des protocoles (IRSN, 2020b), le nombre des examens scanographiques continue de croître globalement dans le monde et le risque correspondant aussi.

Radioprotection a récemment publié des articles traitant de sujets variés liés à l'utilisation du scanner. Par exemple, Asgari et al. ont évalué en Iran les risques de développer des leucémies et cancers du cerveau liés à la réalisation non justifiée de scanners cérébraux (Asgari et al., 2021). La dose à l'organe exposé en scanographie peut être correctement estimée par méthode Monte Carlo (Adrien et al., 2020). La dose scanner reçue par les enfants exposés peut être optimisée en suivant quelques principes pratiques de base (Malchair et Maccia, 2020). Les doses de rayonnements délivrées aux patients pendant les vertébroplasties percutanées peuvent être réduites de façon significative en utilisant un système de navigation assistée par ordinateur (Teriitehau et al., 2020). Les connaissances des manipulateurs de radiologie au sujet des doses délivrées aux patients ont été étudiées en Arabie Saoudite dans le cadre de la radioprotection (Aldhafeeri, 2020).

De nouvelles préoccupations majeures au sujet des doses liées à l'utilisation du scanner sont apparues dans deux revues internationales récentes. Une revue «EuroSafe» de la Société Européenne de Radiologie indique que les doses efficaces cumulées, du fait de la répétition d'examens scanner, peut excéder $100 \mathrm{mSv}$ chez un nombre de patients faible mais significatif: 0,5\% (0-2,72) (Frija et al., 2021), la plupart d'entre eux étant atteints de cancer.

Encore plus frappants sont les résultats d'une vaste étude rétrospective sur les doses scanner reçues en une seule journée. Cette étude a été menée dans 279 hôpitaux de janvier 2015 à décembre 2019 (Rehani et al., 2021). Cette enquête ayant porté sur 3,9 millions de patient-jour s'est intéressée aux protocoles scanner délivrant des doses efficaces $\geq 50 \mathrm{mSv}$ en une seule journée : $9,4 \%$ avaient subi plus d'un scanner, $0,03 \%$ ayant reçu une dose $\geq 100 \mathrm{mSv}$ et $0,8 \%$ une dose $\geq 50 \mathrm{mSv}, 1 / 3$ des patients étant âgés de moins de 50 ans. Les protocoles d'imagerie scanner conduisant à une dose $\geq 50 \mathrm{mSv}$ en un seul jour concernaient le thorax ou l'abdomen et le petit bassin, et presque un tiers d'entre eux étant des examens angiographiques.

Ces deux études indiquent que les patients qui reçoivent de doses $\geq 100 \mathrm{mSv}$ du fait d'examens scanner ne sont pas rares du tout, en particulier dans certains centres. Cela est préoccupant car $100 \mathrm{mSv}$ est le seuil épidémiologique de significativité pour les cancers radioinduits (ICRP, 2007). En conséquence, la justification et l'optimisation des protocoles scanner pour chaque patient, quel que soit son âge et ses antécédents, doivent être renforcées, particulièrement par la formation des médecins et manipulateurs en électroradiologie médicale à la radioprotection des patients, le recours à un physicien médical et l'utilisation des guides de bonnes pratiques concernant les indications (guide du bon usage des examens d'imagerie médicale) et la réalisation des actes (guide des bonnes procédures), afin d'améliorer les pratiques et en diminuer les risques (Habib Geryes et al., 2019). Des systèmes de gestion des doses et d'aide à la décision clinique ont été également élaborés dans ce but.

Pour conclure, les pratiques d'imagerie médicales et tout particulièrement celles utilisant les examens scanographiques doivent faire l'objet d'une attention particulière de la part des praticiens et des radioprotectionnistes. Les articles sur ces sujets sont toujours les bienvenus dans Radioprotection.

\section{Excessive patient doses through computed tomography imaging: new concerns}

Keywords: CT / radiation dose / patient safety / patient risk

It is clearly established that Computed Tomography (CT) imaging is the main contributor $(>50 \%)$ to the dose of ionizing radiation(IR) received by the patients (Dreuil and Etard, 2017; IRSN 2020a). CT imaging is per se a "dosing" examination extensively used because justified for its decisive contribution to the rapid diagnosis of diseases, the staging of cancer, the 
orientation of the therapeutic strategy, the follow-up of disease and the efficacy of treatment and the treatment itself. Even if the implementation of diagnostic reference levels contributes to the optimization of protocols (IRSN, 2020b), the number of CT examinations continue to increase worldwide and the corresponding risk as well.

Various CT issues were recently addressed in Radioprotection. For example, Asgari et al., evaluated in Iran the risk of leukemia and brain tumors from unnecessary CT scans of the brain (Asgari et al., 2021). Organ dose in CT can be well estimated with Monte Carlo (Adrien et al., 2020). CT scanner dose can be optimized in children by following some basic and practical advices (Malchair and Maccia, 2020). Patient radiation dose during percutaneous CT vertebroplasty can be significantly reduced by using computer-assisted navigation (CAN) system (Teriitehau et al., 2020). As part of radiological protection, the radiographers' knowledge regarding patients' ionizing radiation doses has been evaluated in Saudi Arabia (Aldhafeeri, 2020).

New major concerns regarding CT doses come from two recent international surveys. An EuroSafe survey of the European Society of Radiology indicates that cumulative effective doses received from repeated computed CT examinations may exceed $100 \mathrm{mSv}$ in a small but significant percentage of patients: 0.5\% (0-2.72) (Frija et al., 2021), most of them having a cancer.

Even more striking are the results of a large retrospective study on CT doses received in one day and carried out in 279 hospitals from January 2015 to December 2019 (Rehani et al., 2021). This survey of 3.9 million patient-days focused on CT imaging protocols delivering $\geq 50 \mathrm{mSv}$ effective dose in one single day: $9.4 \%$ had more than one CT, $0.03 \%$ with a dose $\geq 100 \mathrm{mSv}$ and $0.8 \%$ with a dose $\geq 50 \mathrm{mSv}, 1 / 3$ of patients being aged $\leq 50$ years. CT imaging protocols leading to $\geq 50 \mathrm{mSv}$ in a single day concerned chest or abdomen and pelvis, nearly one third of them being angiographic studies.

These two studies indicate that patients receiving doses $\geq 100 \mathrm{mSv}$ by CT examinations are not rare at all in particular in some institutions. This is worrying because $100 \mathrm{mSv}$ is the epidemiologic threshold of significance for radio-induced cancers (ICRP, 2007). Consequently, justification and optimization of CT protocols for each patient regardless of age and medical history must be enforced, especially through the training of medical doctors and radiographers, the assistance of medical physicists and the use of referral criteria for imaging and procedure regarding optimization guides, to improve practice and to decrease risk (Habib Geryes et al., 2019). Dose Management and Clinical Decision Support Systems have also been designed to help refining practice.

To conclude, medical imaging practices and especially those using CT deserve a particular attention from practitioners and radiation protectionists. Articles on these issues are always very welcome in Radioprotection.

\section{Références}

Adrien C, Le Loirec C, Dreuil S, Bordy JM. 2020 A new Monte Carlo tool for organ dose estimation in computed tomography. Radioprotection 55(2): $123-134$.

Aldhafeeri FM. 2020. Radiographers' knowledge regarding patients' ionizing radiation doses during common radiological procedures in Saudi Arabia. Radioprotection 55(1): 55-60.

Asgari A, Parach AA, Bouzarjomehri F, Shirani-Takabi F, Mehrparvar AH, Mirmohammadi SJ, Khaksar E. 2021. Projected future risk of leukemia and brain tumors from unnecessary brain CT scans: a multi-center study in Iran. Radioprotection 56(1): 25-32.

Dreuil S, Etard C. 2017 Exposure of the French population to ionizing radiations from medical diagnostic procedures in 2012. Radioprotection 52: $45-49$.

Frija G, Damilakis J, Paulo G, Loose R, Eliseo Vano E, European Society of Radiology (ESR). 2021. Cumulative effective dose from recurrent CT examinations in Europe: proposal for clinical guidance based on an ESR EuroSafe Imaging survey. Eur. Radiol. https://doi.org/10.1007/ s00330-021-07696-1.

Habib Geryes B, Hornbeck A, Jarrige V, Pierrat N, Le Pointe D, Dreuil S. 2019. Patient dose evaluation in computed tomography: A French national study based on clinical indications. Phys. Med. 61: 18-27.

ICRP. 2007. The 2007 Recommendations of the International Commission on Radiological Protection. ICRP Publication 103. Ann. ICRP 37 (2-4).

IRSN. 2020a. Exposition de la population aux rayonnements ionisants due aux actes d'imagerie médicale diagnostique réalisés en France en 2017. https://www.irsn.fr/FR/expertise/rapports_expertise/Documents/radioprotection/IRSN_Rapport_Expri_2019.pdf.

IRSN. 2020b. Analyse des données relatives à la mise à jour des niveaux de référence diagnostiques en radiologie et en médecine nucléaire. Bilan 2016-2018: https://www.irsn.fr/FR/expertise/rapports_expertise/Documents/radioprotection/IRSN_NRD-Bilan-2016-2018Diagnos tic-Medical_202004.pdf.

Malchair F, Maccia C. 2020. Practical advices for optimal CT scanner dose in children. Radioprotection 55(2): 117-122.

Rehani MM, Heil J, Baliyan V. 2021. Eur. Radiol. https://doi.org/10.1007/s00330-021-07734-y.

Teriitehau C, Rabeh H, Pessis E, Sénéchal Q, Besse F, Bravetti M. 2020. Reduction of patient radiation dose during percutaneous CT vertebroplasty: impact of a new computer-assisted navigation (CAN) system. Radioprotection 55(1): 11-16.

Michel Bourguignon Rédacteur en chef 